\title{
encephalitis
}

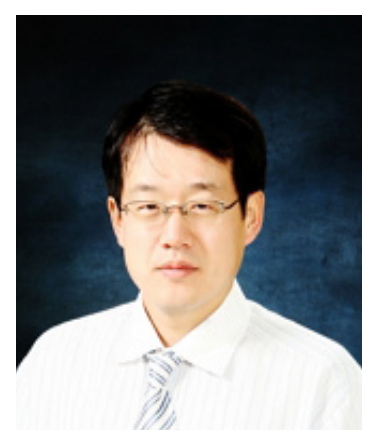

\section{New era exploring the brain}

\author{
Manho Kim \\ Department of Neurology, Seoul National University Hospital, Seoul National University College of \\ Medicine, Seoul, Korea
}

encephalitis is the first official journal of the Korean Encephalitis and Neuroinflammation Society (KENS) which was established in September, 2013.

With delight and deep appreciation, I extend special thanks to all the staff who have spent time and effort to launch the journal, expecting it will be a leader in advanced neurology research.

Even a decade ago, as is the case for most neurologists, patients with encephalitis were regarded as a part of the infection, thus, many of them were managed according to a standard protocol, such as anti-viral agents with seizure or intracranial pressure controls. However, even with rigorous treatment, some patients did not survive or were left with severe neurological deficits. Even the causative agents were not known.

Since the discovery of autoimmune encephalitis, starting with anti- $N$-methyl-D-aspartate receptor encephalitis, experts at this institution developed and began to provide diagnosis guidelines all across the country, along with consultations for clinical practitioners. Several thousand patients' lives were saved. Accumulating experiences have been communicated via lectures at seminars or conferences as well as among the members of KENS.

The discoveries so far are big steps in the exploration of the brain. Expanding datasets are expected and will need to be organized, from case reports to clinical trials, from basic and translational neuroscience to clinical practice, and then systemic reviews to update the new advances.

Now, as the second president of KENS, it is my great honor to celebrate launching the journal, encephalitis.

With my best regards,

Manho Kim

President, Korean Encephalitis and Neuroinflammation Society

Received: December 28, 2020 Accepted: December 31, 2020

Correspondence: Manho Kim

Department of Neurology, Seoul National University Hospital, Seoul National University College of Medicine, 101 Daehak-ro, Jongno-gu, Seoul 03080, Korea

E-mail: kimmanho@snu.ac.kr

ORCID: https://orcid.org/0000-0002-0277-6326

Copyright (C) 2021 by The Korean Encephalitis and Neuroinflammation Society

This is an open access article distributed under the terms of the Creative Commons Attribution Non-Commercial License (http://creativecommons.org/licenses/by-nc/4.0/) which permits unrestricted non-commercial use, distribution, and reproduction in any medium, provided the original work is properly cited. 